\title{
Early recognition of high risk of bipolar disorder and psychosis: an overview of the ZInEP "early recognition" study
}

\section{Anastasia Theodoridou ${ }^{1,2}$, Karsten Heekeren ${ }^{1,2}$, Diane Dvorsky ${ }^{1,2}$, Sibylle Metzler ${ }^{1,2}$, Maurizia Franscini $^{3}$, Helene Haker 1,2,4, Wolfram Kawohl 1,2, Nicolas Rüsch ${ }^{1,2}$, Susanne Walitza ${ }^{3}$ and Wulf Rössler 1,2,5 *}

1 Department of Psychiatry, Psychotherapy and Psychosomatics, University Hospital of Psychiatry Zurich, Zurich, Switzerland

${ }^{2}$ The Zurich Program for Sustainable Development of Mental Health Services (ZInEP), University Hospital of Psychiatry Zurich, Zurich, Switzerland

${ }^{3}$ University Hospital of Child and Adolescent Psychiatry, University of Zurich, Zurich, Switzerland

${ }^{4}$ Translational Neuromodeling Unit, University of Zurich and ETH Zurich, Zurich, Switzerland

${ }^{5}$ Collegium Helveticum, Zurich, Switzerland

\section{Edited by:}

Fotios C. Papadopoulos, Uppsala University, Sweden

Reviewed by:

Leandro Da Costa Lane Valiengo, Universidade de São Paulo, Brazil

Umberto Volpe, Second University of Naples, Italy

Richard Whittington, University of

Liverpool, UK

Caroline Vandeleur, Lausanne

University Hospital, Switzerland

*Correspondence:

Wulf Rössler, Department of

Psychiatry, Psychotherapy and

Psychosomatics, University Hospital

of Psychiatry Zurich, Militärstrasse 8

Zurich 8021, Switzerland

e-mail:roessler@dgsp.uzh.ch
Early detection of persons with first signs of emerging psychosis is regarded as a promising strategy to reduce the burden of the disease. In recent years, there has been increasing interest in early detection of psychosis and bipolar disorders, with a clear need for sufficient sample sizes in prospective research. The underlying brain network disturbances in individuals at risk or with a prodrome are complex and yet not well known. This paper provides the rationale and design of a prospective longitudinal study focused on at-risk states of psychosis and bipolar disorder. The study is carried out within the context of the Zurich Program for Sustainable Development of Mental Health services (Zürcher Impulsprogramm zur Nachhaltigen Entwicklung der Psychiatrie). Persons at risk for psychosis or bipolar disorder between 13 and 35 years of age are examined by using a multi-level-approach (psychopathology, neuropsychology, genetics, electrophysiology, sociophysiology, magnetic resonance imaging, near-infrared spectroscopy). The included adolescents and young adults have four follow-ups at $6,12,24$, and 36 months. This approach provides data for a better understanding of the relevant mechanisms involved in the onset of psychosis and bipolar disorder, which can serve as targets for future interventions. But for daily clinical practice a practicable "early recognition" approach is required. The results of this study will be useful to identify the strongest predictors and to delineate a prediction model.

Keywords: bipolar disorder, psychosis, early recognition, high risk, ZInEP

\section{INTRODUCTION}

Early detection and prevention is considered an essential strategy to reduce years lived with disability (YLD) and reduce the stigma attached to mental disorders (1). However, in some people the initial symptoms are not properly recognized $(2,3)$. Lack or delay of treatment can lead to an unfavorable or chronic course of the illness $(4,5)$. Research on the psychosis risk syndrome, which aims to reduce transition rates to psychosis, presents a challenge to current ascertainment and intervention methods (6). Some at-risk individuals do not convert to psychosis, but have outcomes that fall within the spectrum of psychotic disorders. Therefore, it is necessary to improve knowledge about prediction. Currently, new methodological approaches such as multivariate modeling and machine learning methods are discussed in regard to the prospects and caveats (7-10). At the same time, the field is moving toward extending efforts to study the bipolar disorder risk syndrome (11).

The first phase of research into early recognition of psychosis tended to favor specific assessment tools, definition of high-risk (HR) criteria and outcomes as well as the application of these methods (11-14). Even if the duration of untreated psychosis (DUP) has been shortened in the last years, an average of 1 year
DUP in highly developed health care systems remains (15). But once basic symptoms and "ultra-high risk" (UHR)-symptoms are detectable, associated pathophysiology may have already progressed (16). Assuming that the brain is a complex structure in which anatomical and functional connectivity occurs at many levels (17), that plasticity occurs during all stages of development and that environmental factors can also have important effects on brain functions, psychiatry must take various levels of evidence into account (18). To detect this underlying pathophysiology, putative biomarkers, and intermediary phenotypes need to be developed and tested in a sufficiently large cohort with members truly at risk for psychosis (14). The diagnostic process of bipolar disorder is made more difficult, especially in young people, by complex diagnostic conditions from which bipolar disorder must be distinguished and also from the occurrence of adverse life circumstances, all of which do not facilitate the diagnostic process (19). A combination of clinical risk factors with precursors and family-risk could improve early identification of bipolar disorder (20). Even though there is evidence suggesting that the characterization of early phases in the development of the bipolar disorder is viable further evaluation in larger, prospective studies is needed (21-24). 
There is evidence for a substantial overlap in genetic susceptibility to bipolar disorder and schizophrenia but also for the existence of non-shared genetic risk factors (25-27). However, attenuated positive symptoms occur in both the schizophrenic and the bipolar prodromal phase $(22,28,29)$. Potential analogy between the genetic and phenotypic overlap between both phases raises the question about the nature of the at-risk phase of different mental disorders.

Previous research into the prodromal phase of first-episode psychosis has brought knowledge regarding the development of psychosis (30). But until now it is unclear to what extent the findings from research into the prodromal phase of first-episode psychosis reflect psychiatric distress in general and to what extent they are specifically associated with the development of a fullblown psychotic disorder (30). It may be that a more general strategy for early intervention in a range of mental disorders could be a useful approach. Many disorders could develop from initial non-specific symptoms and syndromes, i.e., from a background of specific and non-specific risk factors (31). Understanding the interplay of developmental factors and pathophysiological changes will help to study the moderating risk and resilience factors.

Main objective of the ZInEP "early recognition" study is to develop a risk model to estimate conversion risk and to specify how environmental and pathophysiological factors affect functioning. We hypothesize that our defined at-risk groups for psychosis and bipolar disorder could be distinguished based on the neurocognitive and neurobiological measures. In this paper, we present an overview of the study methodology and the characteristics of the sample recruited so far.

\section{MATERIALS AND METHODS STUDY DESIGN}

The Zurich Early Recognition Program [part of The Zurich Program for Sustainable Development of Mental Health services (Zürcher Impulsprogramm zur nachhaltigen Entwicklung der Psychiatrie; www.zinep.ch)] is based in a catchment area in the Canton Zurich, Switzerland with approximately 1,300,000 inhabitants. Our study has a longitudinal multi-level design with a baseline assessment and four follow-up examinations at 6, 12, 24, and 36 months or if transition to full-blown psychotic or affective disorder occurs.

\section{REFERRAL AND RECRUITMENT}

All persons in the indicated age range (subjects between 13 and 35 years of age) presenting to any of our four study centers, situated in urban area, and embedded into established early recognition units, were screened for the presence of the inclusion criteria. Psychiatrists, child and adolescent psychiatrists, psychologists, general practitioners, outreach clinics, counseling services, teachers, and affected persons or their worried family members could refer to the early recognition units (hospital based units employing standardized criteria to identify persons at risk for psychosis or bipolar disorder and offering appropriate counseling). We provided information about the study through local workshops, articles in professional journals, flyers, and a study-website. If at least one inclusion criterion was fulfilled and the participants gave written informed consent, the baseline examination including clinical (including blood analysis), psychopathological, neurocognitive, neurophysiological, genetic, sociophysiological, and magnetic resonance $(\mathrm{MR})$ measures were performed. We also recruited normal control subjects from the community by way of advertisements. They were healthy volunteers, aged 13-35 years, without any personal history of psychiatric illness including schizophrenia, bipolar, or other psychotic disorders.

\section{PARTICIPANTS}

For inclusion, participants had to fulfill at least one of the following three criteria (listed in Table 1): (i) HR status for psychosis assessed by the adult $(14)$ or children-youth $(32,33)$ version of the Schizophrenia Proneness Interview, with at least one cognitiveperceptive basic symptom or at least two cognitive disturbances; or (ii) ultra-HR status (UHR) for psychosis as rated by the Structured Interview for Prodromal Syndromes (SIPS) $(12,34)$ with at least one attenuated psychotic symptom, or at least one brief limited intermittent psychotic symptom, or state-trait criteria [reduction in global assessment of functioning (GAF) of $>30 \%$ in the past year plus either schizotypal personality disorder or a first degree relative with psychosis]; or (iii) risk of bipolar disorder (at-risk bp), defined by a score $\geq 14$ in the hypomania checklist, a self-report measure of life-time hypomanic symptoms (35).

Exclusion criteria for study participation were diagnosed schizophrenic, substance-induced or organic psychosis, other symptomatic organic mental disorders, manifest bipolar disorder, current substance, or alcohol dependence, age below 13 or above 35 years, incapacity to consent, e.g., due to an acute and severe psychopathological state or low intellectual abilities with IQ $<80$. Axis-I comorbidity was assessed by the Mini-International Neuropsychiatric Interview based on DSM-IV criteria (36). The presence of psychotic symptoms for more than 1 week was assessed. Transition to psychosis or bipolar disorder was defined according to ICD-10 criteria.

\section{INFORMED CONSENT}

Adult and young persons were informed about the study by a research-psychologist or research-psychiatrist by means of a comprehensive information letter. When all the information on the trial was understood, the consent form was signed (up to age 18 by both the adolescent and their parents) and the person was invited for the first screening. Participants could always withdraw from

\section{Table 1 | Risk groups.}

\section{High-risk (HR) for psychosis}

at least one cognitive-perceptive basic symptom or at least two cognitive disturbances

\section{Ultra-high-risk (UHR) for psychosis}

at least one attenuated psychotic symptom or at least one brief limited intermittent psychotic symptom or state-trait criteria (reduction in global assessment of functioning of $>30 \%$ in the past year plus either schizotypal personality disorder or a first degree relative with psychosis)

Risk of bipolar disorder (at-risk bp)

defined by a score $\geq 14$ in the Hypomania Checklist 
participating in the study. The study was approved by the local ethics committee and conducted in accordance with the guidelines of the Helsinki Declaration.

\section{ASSESSMENTS}

A multi-level assessment of psychopathology, neurocognitive, neurophysiological, genetic, structural, and functional brain abnormalities is carried out.

Information on psychopathology was gathered with the Schizophrenia Prediction Instrument-adult (14) and -child and youth Version (SPI-CY, SPI-A) $(32,33)$, the SIPS $(12,34)$, the Positive and Negative Symptom Scale (PANSS) (37), Hypomania Checklist (HCL-32) (35), Calgary Depression Scale (38), Hamilton Depression Scale (HAMD) (39), and Beck Anxiety Inventory (BAI) (40).

Data about the socio-demographic background, physical health, obstetric and family history, premorbid adjustment, functioning and disability by psychiatric symptoms, daily hassles stress, and quality of life were collected via: Obstetric Complications Scale (OCS) (41), Clinical Global Impression Rating Scales (CGI) (42), GAF (43), Hopkins Symptom Checklist (SCL-90-R) (44), Camberwell Assessment of Need (CAN) (45), the General SelfEfficacy-Scale (GSE) (46), Daily Hassles and Stress Scale (DHSS) (47), Manchester Short Assessment of Quality of Life (MANSA) (48). All investigators were either psychologists or psychiatrists who received extensive training.

\section{NEUROCOGNITIVE ASSESSMENTS}

A set of well-established neuropsychological tests was administered in accordance with the MATRIC Consensus Cognitive Battery (49-51). Verbal IQ was estimated with a word recognition test (MWT-B) for adults (52) and a test of receptive vocabulary for adolescents (PPVT) (53). Abstract reasoning abilities were estimated using a non-verbal task (scale 3 of LPS) (54). Measures of attention were assessed by Continuous Performance Test (CPTOX) (55), a test of selective attention (FAIR) (56), the Stroop Test (57), and the divided attention subtest of a computer-administered test series (TAP) (58). The Trail Making Test Parts A and B (59) were used to assess psychomotor speed, attention, and cognitive flexibility.

Measures of verbal and figural learning and memory were collected from a German Auditory Verbal Learning Test $(60,61)$ and from the Rey Visual Design Learning Test (57).

Measures of executive function were provided by a test of verbal (RWT) and figural (five-point test) fluency $(62,63)$, working memory by subtests of the Wechsler Adult Intelligence Scale (WIE) (64), a computer-administered Wisconsin Card Sorting Test (CKV) (65), and Tower of Hanoi (ToH) (66).

\section{MOLECULAR GENETIC STUDIES}

Genetic and epigenetic studies will be carried out in the Neurobiochemistry Laboratory of the University Hospital of Child and Adolescent Psychiatry (E. Grünblatt, S. Walitza) together with the Institute of Medical Genetics, University of Zurich (A. Rauch). Peripheral blood samples were collected from at-risk individuals for DNA and RNA (PAXgene Blood RNA Tubes) analysis. For gene expression profiling, RNA was reverse-transcribed into
cDNA using the iScript cDNA synthesis kit. Using quantitative real-time RT-PCR, the profile of transcript for various genes was investigated. DNA is available from 218 participants, of whom $2 / 3$ are adolescents while the other $1 / 3$ are young adults. Various candidate gene variations (SNPs and polymorphism) and gene expression analyses have been performed up to now (e.g., D-amino acid oxidase activator, dopamine transporter, neuroregulin). Genome wide CNV analysis in at-risk persons for psychosis and bipolar disorders is still on-going.

\section{MAGNETIC RESONANCE IMAGING}

Images were collected on a Philips Achieva 3 Tesla magnetic resonance imaging (MRI) scanner equipped with an 8-channel standard head coil. The MR-images of all participants were rated by the Department of Neuroradiology at the University of Zurich for exclusion of a visible organic brain disease.

The intended analyses of the MRI data include voxel based morphometry (VBM) and diffusion tensor imaging (DTI) to detect alterations of the cortical structure and the white matter in individuals at-risk. Intrinsic functional connectivity is examined based on resting state functional MRI data (6-min runs). In addition, a reward task [Monetary Incentive Delay Task (67)] was performed to identify possible dysregulations of the dopaminergic system by investigating the neural responses to reward expectation and reward outcomes.

\section{CLINICAL NEUROPHYSIOLOGY}

EEG data are recorded with a BrainAmp 32 channel-amplifier. Brain Vision Recorder is used as the recording software (both Brain Products GmbH, Munich, Germany). Silver/silver-chlorideelectrodes attached to nylon caps [BrainCap with 32 channels (Easycap, Herrsching-Breitbrunn, Germany)] in accordance with the international 10\%-system are applied to the scalp. Impedances are strictly kept below $10 \mathrm{k} \Omega$. EEG Channels are referenced to FCz.

The following electroencephalographic paradigms were used in the study.

\section{Somatosensory evoked potentials}

Human median nerve somatosensory evoked potentials (SEP) provide the possibility of investigating thalamocortical and early cortical processing (68). SEP of the median nerve show brief highfrequency oscillations $(\sim 600 \mathrm{~Hz})$, which underlie the primary cortical low-frequency negative peak $20 \mathrm{~ms}$ after stimulation. Altered latency and amplitude of SEP have been shown to be present in schizophrenia (69).

\section{Loudness dependence of auditory evoked potentials}

The loudness dependence of auditory evoked potentials (LDAEP) is considered to be an indicator of the brain's serotonergic functioning. Moreover, there are hints of influences of other neurotransmitters than serotonin $(70,71)$. The LDAEP is altered in patients with schizophrenia (72-75). Stimulus tones of five intensities $(60,70,80,90$, and $100 \mathrm{~dB})$ were presented.

\section{Mismatch negativity}

The mismatch negativity (MMN) is supposed to reflect an automatic, preattentive process for change detection $(76,77)$. A dysfunction in the glutamatergic receptor system is considered to play 
an important role in schizophrenia-related deficits in MMN (78, 79). In the present study, the MMN paradigm includes changes in frequency, intensity, and duration of tones in repetitive acoustic stimulation.

\section{NoGo anteriorization}

For the investigation of response control, i.e., the execution (Go) and the inhibition (NoGo) of an anticipated motor response, the continuous performance test (CPT) (55) was used. The gravity center (centroid) of the ERP elicited during the NoGo-condition is located more anteriorly as compared to the Go-condition in healthy subjects and this effect has been reported to be smaller in patients with schizophrenia $(80,81)$.

\section{Near-infrared spectroscopy}

Changes in frontal oxygenation parameters $\mathrm{O} 2 \mathrm{Hb}$ and $\mathrm{HHb}$ are measured with a 52-channel near-infrared spectroscopy-system, Optical Topography ${ }^{\circledR}$ System (Hitachi ETG-4000), light sources within this system are 18 semiconductor lasers of 695 and $830 \mathrm{~nm}$ wavelength. For the positioning of the fibreoptics probes with distances of $30 \mathrm{~mm}$ between signal and detector are used (both Hitach Medical Corporation, Tokyo, Japan). Data sampling rate is set as 10 samplings per second. Measurement channels cover large areas of the prefrontal cortex, motor, and premotor regions and superior temporal cortex.

Cognitive paradigms employed in the neurophysiological examinations included the Verbal-Fluency Test (semantic and phonemic) performed according to Ehlis et al. (82) and Hermann et al. (83), and the emotional Stroop Test $(84,85)$.

\section{SOCIOPHYSIOLOGY AND SOCIAL COGNITION}

Motor empathy was assessed using the Resonance Test $(86,87)$. In this behavioral paradigm, contagion by yawning and laughing is rated while participants view short video sequences of yawning and laughing faces.

Different aspects of visual emotion recognition in faces were assessed using several items of the "University of Pennsylvania Computerized Neuropsychological Testing Systems" (88): Penn Facial Memory Test (89), Penn Emotion Recognition Task (90), Penn Emotion Discrimination Task (91), and Penn Facial Emotion Acuity Task (92).

Visual recognition of complex emotions and intentions was assessed using the reading the mind in the eyes task (93).

Social attribution style according to the theory of Kelley and Levine (94) was assessed including a paradigm developed by Rössler and Lackus (95).

The ability to differentiate between self and other on the level of visual feedback to motor actions was assessed using a source monitoring or agency task $(96,97)$.

Subjective experience of empathic abilities was assessed using the Interpersonal Reactivity Index 28-item Self-Report Questionnaire that comprises four subscales: fantasy scale, empathic concern, perspective taking, and personal distress $(98,99)$.

\section{STIGMA MEASURES}

Perceived stigma was assessed using the 12-item Perceived Devaluation-Discrimination Questionnaire (100). Three items measured perceived legitimacy of discrimination or whether participants felt discrimination against people with mental illness was fair $(101,102)$. General self-esteem was examined using the 10-item Rosenberg Self-Esteem Scale (103). The desire for social distance from people with mental illness was measured using a 5-item Social Distance Scale (104). We used eight items to assess the cognitive appraisal of stigma as a stressor $(105,106)$, adapted from Kaiser and colleagues (107). The perception of people with mental illness as a distinct and coherent group in society (entitativity) was measured using four items (108). Group values were assessed by two items on whether respondents felt people with mental illness were a good group in society. The level of identification with the group of people with mental illness was examined by five items $(101,109)$.

\section{SAMPLE}

In 28 months, 305 persons were screened. Eligible participants $(n=273)$ gave informed consent to participate in the study; 52 withdrew their consent before baseline examination was completed. Therefore, 221 persons entered the study group, of whom $133(60.2 \%)$ were male. The mean age of the sample was 20.99 $( \pm 6.0)$ years (range $13-35$ years, median 20 years) with no significant difference between males $(21.25 \pm 6.1$ years $)$ and females $(20.60 \pm 5.7$ years $)$.

Among the 221 subjects, most reported COPER (70.1\%), COGDIS (53.4\%), and APS (44.3\%). Genetic risk plus reduced functioning criterion $(7.2 \%)$ as well as BLIPS (3.6\%) were reported noticeably less frequently. Further, 155 (70.1\%) subjects showed 14 or more symptoms on the Hypomania Checklist (HCL-32) and $133(60.2 \%)$ had a score of 12 or more on the HAMD. Also, 147 $(66.5 \%)$ subjects had a score of 10 or more on the BAI.

Of the subjects, $28.1 \%$ met only one inclusion criterion, $43.8 \%$ met two and $28.1 \%$ met all three inclusion criteria (HR, UHR, at-risk bp). Only a small group of 3.2\% (7 subjects) was included on the basis of cognitive disturbances alone.

Among the 221 participants, 81 (36.7\%) fulfilled high risk and 107 (48.4\%) UHR criteria for psychosis, 155 (70\%) fulfilled risk criteria for bipolar disorder.

\section{DISCUSSION}

During the last decades, there has been a considerable increase of Early Recognition and Intervention services. While "HR" studies in psychosis are numerous "HR" research in bipolar disorder are emerging. Conceptualization of early recognition of at-risk phases of psychosis and bipolar disorder is complicated due to the mix of heterogeneity and overlap regarding genetic and phenomenological aspects. The ZInEP “early recognition” longitudinal study aims to better understand the predictors of psychosis/bipolar disorder onset and mechanisms for the development of both disorders.

Focusing on both the psychosis at-risk and the bipolar at-risk group, we confirm an overlap between the different at-risk groups.

Recently, the European Prediction of Psychosis Study (EPOS) group suggested a 2-step risk assessment, with UHR and cognitive disturbance criteria for general risk and the prognostic scores as a second-step tool for further risk classification. They propose testing a multi-level model including additional neurocognitive, neurobiological, socio-biographical, and environmental variables 
to see if this model increases predictive accuracy (8). Similarly to EPOS and contrary to NAPLES (110) our group shows a lower proportion of persons with a positive family history. With 221 persons included in the ZInEP "early recognition-sample" we aim to improve individual risk assessment by developing an optimized prediction model. Focusing in addition on the putative "at-risk bipolar" group, we will have the opportunity to test the proposed risk criteria for bipolar disorder.

The development of at-risk criteria for first-episode psychosis is advanced in comparison to the developmental stage of the at-risk criteria for first-episode mania. Currently, there is no consensus on the definition of the bipolar prodrome (111). Further investigation of subthreshold symptoms is needed to identify potential prodromal symptoms. After completing the follow-up period it will be possible to refine the risk criteria for true "at-risk bipolar” individuals. Adding, e.g., imaging or neuropsychological data could further increase their predictive power (112). The bipolar-spectrum concept may also provide research for affective disorders by facilitating identification of early stage bipolar disorder (113). The concept, as suggested by Angst et al., comprises a continuum of severity and a continuum from depression to mania, providing a more differentiated research model for affective disorders. This corresponds to the genetic findings as quoted previously.

A dimensional approach with a focus on the major components of these disorders, i.e., mania, psychosis (and depression) could be a helpful strategy to disentangle subjects at-risk for mania and those at-risk for psychosis. Examinations of the familial aggregation patterns of the core components of psychosis, mania, and major depression suggest a strong familial specificity (114). Familial aggregation of bipolar disorder seems to be attributed to mania (115). Family studies demonstrated the independence of the familial transmission of mania and depression $(114,115)$.

Age also seems to play an important role in the distribution pattern of the different risk states with assumed different trajectories. In our sample, we will be able to examine, if the "adolescent risk-sample" differs significantly from the "adult risk-sample" in the symptom distribution. The adolescent group may develop a higher symptom load at an earlier stage, which could correlate with marked increases in neurobiological changes. Besides the on-going follow-up examination, we will analyze our recent data regarding potential correlations with data from genetic, neuropsychology, electrophysiology, MRI, sociophysiology/social cognition, stigma, resilience, stress coping, and environmental factors.

Up to now in our sample risk group, affiliation and transition to psychosis were predicted by different neuropsychological deficits, which also had a profound effect on an individual's level of general functioning and satisfaction with life (116).

Addington and Heinssen point out that an improved prediction model should also include biomarkers (117). Using refined prediction models will help understand the development of psychotic disorders. But taking into account that a subgroup, even if they do not develop full-blown psychosis, does not necessarily experience complete remission of symptoms or improvement in functioning either, it is necessary to consider the possibility of being at-risk for mental disorders other than psychosis (118).
Also, improved prediction models encourage research on early intervention in persons with a higher risk for psychosis. Understanding the biological and environmental mechanisms involved in the onset of psychosis will help to discover potentially diseasemodifying interventions. Trying to overcome problems, which arise due to categorical diagnosis, augmentation with symptom, time, severity, and persistence dimensions were recently suggested (119). Their proponents state that a prevention-oriented framework for evaluation of interventions can be provided by defining discrete stages according to progression of disease.

But early detection could unintentionally entail the "mental illness" label and may negatively affect service use. In our sample stronger self-labeling and less stigma stress predicted better attitudes toward psychiatric medication and psychotherapy. In addition, stigma stress, but not the level of perceived public stigma, predicted more negative attitudes toward help-seeking (120). Perceived public stigma appears to be associated with reduced wellbeing among young people at-risk of psychosis (121). Well-being is influenced moreover by changes of self-labeling and stigma stress over time independent of baseline levels (122). A non-stigmatizing use of (self-) labeling could reduce stigma stress and its impact on young people at-risk for psychosis (120). This highlights the need for specific interventions regarding stigma.

Despite the considerable evidence, which has been accumulated on early recognition of psychosis, there is a shortage of research findings regarding (a) the underlying biological mechanisms, (b) valid risk criteria for bipolar disorder, and (c) the developmental trajectories. The ZInEP "early recognition"-study enables to test the possible contributions of this multi-level-approach and thereby to contribute to an improved prediction.

\section{AUTHOR CONTRIBUTIONS}

The international advisory board includes Gerd Glaeske, Thomas Becker, Andreas Fallgatter, Felix Gutzwiller, Joachim Klosterkötter, Christoph Lauber, Roselind Lieb, Ulrich Meise, Hans Joachim Salize, and Wolfgang Wölwer. Anastasia Theodoridou, Karsten Heekeren, Helene Haker, Wolfram Kawohl, Nicolas Rüsch, Susanne Walitza, and Wulf Rössler designed the study. Diane Dvorsky, Sibylle Metzler, and Maurizia Franscini acquired the data. Anastasia Theodoridou drafted and revised the manuscript, which all authors reviewed and approved for publication.

\section{ACKNOWLEDGMENTS}

The study is funded by a private foundation. The funding is in accordance with the legal requirements and was approved by the Ministry of Health of the Canton of Zurich (Switzerland). The funding body did not play any role in devising the study design. We thank Heather Murray for language editing on a freelance basis.

\section{REFERENCES}

1. World Health Organization. Prevention of Mental Disorders: Effective Interventions and Policy Options. Geneva: World Health Organization (2004).

2. Rössler W, Riecher-Rössler A, Angst J, Murray R, Gamma A, Eich D, et al. Psychotic experiences in the general population: a twenty-year prospective community study. Schizophr Res (2007) 92(1-3):1-14. doi:10.1016/j.schres.2007. 01.002

3. Rössler W, Angst J, Gamma A, Haker H, Stulz N, Merikangas KR, et al. Reappraisal of the interplay between psychosis and depression symptoms in the 
pathogenesis of psychotic syndromes: results from a twenty-year prospective community study. Eur Arch Psychiatry Clin Neurosci (2011) 261(1):11-9. doi:10.1007/s00406-010-0123-0

4. Marshall M, Lewis S, Lockwood A, Drake R, Jones P, Croudace T. Association between duration of untreated psychosis and in cohorts of first-episode outcome patients: a systematic review. Arch Gen Psychiatry (2005) 62(9):975-83. doi:10.1001/archpsyc.62.9.975

5. Perkins DO, Gu H, Boteva K, Lieberman JA. Relationship between duration of untreated psychosis and outcome in first-episode schizophrenia: a critical review and meta-analysis. Am J Psychiatry (2005) 162(10):1785-804. doi:10.1176/appi.ajp.162.10.1785

6. McGorry PD, Nelson B, Amminger GP, Bechdolf A, Francey SM, Berger G, et al. Intervention in individuals at ultra-high risk for psychosis: a review and future directions. J Clin Psychiatry (2009) 70(9):1206-12. doi:10.4088/ ICP.08r04472

7. Cannon TD, Cadenhead K, Cornblatt B, Woods SW, Addington J, Walker E, et al. Prediction of psychosis in youth at high clinical risk: a multisite longitudinal study in North America. Arch Gen Psychiatry (2008) 65(1):28-37. doi:10.1001/archgenpsychiatry.2007.3

8. Ruhrmann S, Schultze-Lutter F, Salokangas RK, Heinimaa M, Linszen D, Dingemans $\mathrm{P}$, et al. Prediction of psychosis in adolescents and young adults at high risk: results from the prospective European prediction of psychosis study. Arch Gen Psychiatry (2010) 67(3):241-51. doi:10.1001/archgenpsychiatry.2009.206

9. Koutsouleris N, Ruhrmann S, Falkai P, Maier W. [Personalised medicine in psychiatry and psychotherapy. A review of the current state-of-the-art in the biomarker-based early recognition of psychoses]. Bundesgesundheitsblatt Gesundheitsforschung Gesundheitsschutz (2013) 56(11):1522-30. doi:10.1007/ s00103-013-1840-0

10. Koutsouleris N, Riecher-Rössler A, Meisenzahl EM, Smieskova R, Studerus E, Kambeitz-Ilankovic L, et al. Detecting the psychosis prodrome across high risk populations using neuroanatomical biomarkers. Schizophr Bull (2014). doi:10.1093/schbul/sbu078

11. Correll CU, Hauser M, Auther AM, Cornblatt BA. Research in people with psychosis risk syndrome: a review of the current evidence and future directions. J Child Psychol Psychiatry (2010) 51(4):390-431. doi:10.1111/j.14697610.2010.02235.x

12. Miller TJ, McGlashan TH, Rosen JL, Cadenhead K, Cannon T, Ventura J, et al. Prodromal assessment with the structured interview for prodromal syndromes and the scale of prodromal symptoms: predictive validity, interrater reliability, and training to reliability. Schizophr Bull (2003) 29(4):703-15. doi:10.1093/oxfordjournals.schbul.a007040

13. Yung AR, Yuen HP, McGorry PD, Phillips LJ, Kelly D, Dell'Olio M, et al. Mapping the onset of psychosis: the comprehensive assessment of at-risk mental states. Aust N Z J Psychiatry (2005) 39(11-12):964-71. doi:10.1080/j.14401614.2005.01714.x

14. Schultze-Lutter F, Addington J, Ruhrmann S, Klosterkötter J. Schizophrenia Proneness Instrument, Adult Version (SPI-A). Roma: Giovanni Fioriti Editore (2007).

15. Schultze-Lutter F, Ruhrmann S, Berning J, Maier W, Klosterkötter J. Basic symptoms and ultrahigh risk criteria: symptom development in the initial prodromal state. Schizophr Bull (2010) 36(1):182-91. doi:10.1093/schbul/sbn072

16. Klosterkötter J, Schultze-Lutter F, Bechdolf A, Ruhrmann S. Prediction and prevention of schizophrenia: what has been achieved and where to go next? World Psychiatry (2011) 10(3):165-74. doi:10.1002/j.2051-5545.2011.tb00044.x

17. Bullmore E, Sporns O. Complex brain networks: graph theoretical analysis of structural and functional systems. Nat Rev Neurosci (2009) 10:186-98. doi:10.1038/nrn2575

18. Craddock N, Owen MJ. The Kraepelinian dichotomy - going, going...but still not gone. Br J Psychiatry (2010) 196:92-5. doi:10.1192/bjp.bp.109.073429

19. Carlson GA. Differential diagnosis of bipolar disorder in children and adolescents. World Psychiatry (2012) 11(3):146-52. doi:10.1002/j.2051-5545.2012. tb00115.x

20. Faedda GL, Serra G, Marangoni C, Salvatore P, Sani G, Vázquez GH, et al. Clinical risk factors for bipolar disorders: a systematic review of prospective studies. J Affect Disord (2014) 168C:314-21. doi:10.1016/j.jad.2014.07.013

21. Bauer M, Juckel G, Correll CU, Leopold K, Pfennig A. Diagnosis and treatment in the early illness phase of bipolar disorders. Eur Arch Psychiatry Clin Neurosci (2008) 258(Suppl 5):50-4. doi:10.1007/s00406-008-5009-z
22. Brietzke E, Mansur RB, Soczynska JK, Kapczinski F, Bressan RA, McIntyre RS. Towards a multifactorial approach for prediction of bipolar disorder in at risk populations. J Affect Disord (2012) 140(1):82-91. doi:10.1016/j.jad.2012. 02.016

23. Bechdolf A, Ratheesh A, Cotton SM, Nelson B, Chanen AM, Betts J, et al. The predictive validity of bipolar at-risk (prodromal) criteria in help-seeking adolescents and young adults: a prospective study. Bipolar Disord (2014) 16(5):493-504. doi:10.1111/bdi.12205

24. Correll CU, Olvet DM, Auther AM, Hauser M, Kishimoto T, Carrión RE, et al. The bipolar prodrome symptom interview and scale-prospective (BPSS-P): description and validation in a psychiatric sample and healthy controls. Bipolar Disord (2014) 16(5):505-22. doi:10.1111/bdi.12209

25. Lichtenstein P, Yip BH, Björk C, Pawitan Y, Cannon TD, Sullivan PF, et al. Common genetic determinants of schizophrenia and bipolar disorder in Swedish families: a population-based study. Lancet (2009) 373:234-9. doi:10.1016/ S0140-6736(09)60072-6

26. Potash JB, Bienvenu OJ. Shared genetics of bipolar disorder and schizophrenia. Nat Rev Neurol (2009) 5:299-300. doi:10.1038/nrneurol.2009.71

27. Owen MJ, Craddock N, Jablensky A. The genetic deconstruction of psychosis. Schizophr Bull (2007) 33(4):905-11. doi:10.1093/schbul/sbm053

28. Correll CU, Penzner JB, Frederickson AM, Richter JJ, Auther AM, Smith CW, et al. Differentiation in the preonset phases of schizophrenia and mood disorders: evidence in support of a bipolar mania prodrome. Schizophr Bull (2007) 33(3):703-14. doi:10.1093/schbul/sbm028

29. Skjelstad DV, Malt UF, Holte A. Symptoms and signs of the initial prodrome of bipolar disorder: a systematic review. J Affect Disord (2010) 126:1-13. doi:10.1016/j.jad.2009.10.003

30. Fusar-Poli P, Borgwardt S, Bechdolf A, Addington J, Riecher-Rössler A, Schultze-Lutter F, et al. The psychosis high-risk state: a comprehensive state of the art review. JAMA Psychiatry (2013) 70(1):107-20. doi:10.1001/ jamapsychiatry.2013.269

31. Yung AR, Woods SW, Ruhrmann S, Addington J, Schultze-Lutter F, Cornblatt BA, et al. Whither the attenuated psychosis syndrome? Schizophr Bull (2012) 38(6):1130-4. doi:10.1093/schbul/sbs108

32. Schultze-Lutter F, Koch E. Schizophrenia Proneness Instrument, Child and Youth Version (SPI-CY). Roma: Giovanni Fioriti Editore (2009).

33. Fux L, Walger P, Schimmelmann BG, Schultze-Lutter F. The Schizophrenia proness instrument, child and youth version (SPI-CY): practicability and discriminative power. Schizophr Res (2013) 146:69-78. doi:10.1016/j.schres.2013. 02.014

34. McGlashan TH, Miller TJ, Woods SW. Structured Interview for Prodromal Syndromes (version 3.0). New Haven: PRIME Research Clinic, Yale School of Medicine (2001).

35. Angst J, Adolfsson R, Benazzi F, Gamma A, Hantouche E, Meyer TD, et al. The HCL-32: towards a self-assessment tool for hypomanic symptoms in outpatients. J Affect Disord (2005) 88(2):217-33. doi:10.1016/j.jad.2005.05.011

36. Sheehan DV, Lecrubier Y, Sheehan KH, Amorim P, Janavs J, Weiller E, et al. The mini-international neuropsychiatric interview (M.I.N.I.): the development and validation of a structured diagnostic psychiatric interview for DSMIV and ICD-10. J Clin Psychiatry (1998) 59(Suppl):2022-33.

37. Kay SR, Fiszbein A, Opler LA. The positive and negative syndrome scale (PANSS) for schizophrenia. Schizophr Bull (1987) 13(2):261-76. doi:10.1093/ schbul/13.2.261

38. Addington D, Addington J, Maticka-Tyndale E, Joyce J. Reliability and validity of a depression rating scale for schizophrenics. Schizophr Res (1992) 6(3):201-8. doi:10.1016/0920-9964(92)90003-N

39. Hamilton M. A rating scale for depression. JNeurol Neurosurg Psychiatry (1960) 23:56-62. doi:10.1136/jnnp.23.1.56

40. Steer RA, Beck AT, Zalaquett CP. Beck anxiety inventory. In: Richard John W, editor. Evaluating Stress: A Book of Resources. (Vol. xvii), Lanham, MD: Scarecrow Education (1997). p. 23-40.

41. Owen MJ, Lewis SW, Murray RM. Obstetric complications and schizophrenia: a computed tomographic study. Psychol Med (1988) 18(2):331-9. doi:10.1017/S003329170000787X

42. Guy W. ECDU Assessment Manual for Psychopharmacology. Rockville, MD: U.S. Department of Health EaW (1976).

43. Hall RC. Global assessment of functioning. A modified scale. Psychosomatics (1995) 36:267-75. 
44. Derogatis LR, Lipman RS, Covi L. Hopkins symptom checklist (SCL-90-R). Mod Probl Pharmacopsychiatry (1974) 7:79-110.

45. Phelan M, Slade M, Thornicroft G, Dunn G, Holloway F, Wykes T, et al. The Camberwell assessment of need: the validity and reliability of an instrument to assess the needs of people with severe mental illness. Br J Psychiatry (1995) 167:589-95. doi:10.1192/bjp.167.5.589

46. Schwarzer R, Jerusalem M. Generalized self-efficacy scale. In: Weinman J, Wright S, Johnston M, editors. Measures in Health Psychology: A User's Portfolio. Causal and Control Beliefs. Windsor: NFER-NELSON (1995). p. 35-7.

47. Kohn PM, Macdonald JE. Daily hassles and stress scale. The survey of recent life experiences: a decontaminated hassles scale for adults. J Behav Med (1992) 15:221-36. doi:10.1007/BF00848327

48. Priebe S, Huxley P, Knight S, Evans S. Application and results of the Manchester short assessment of quality of life (MANSA). Int J Soc Psychiatry (1999) 45(1):7-12. doi:10.1177/002076409904500102

49. Kern RS, Nuechterlein KH, Green MF, Baade LE, Fenton WS, Gold JM, et al. The MATRICS consensus cognitive battery, part 2: conorming and standardization. Am J Psychiatry (2008) 165(2):214-20. doi:10.1176/appi.ajp.2007.07010043

50. Nuechterlein KH, Green MF, Kern RS, Baade LE, Barch DM, Cohen JD, et al. The MATRICS consensus cognitive battery, part 1: test selection, reliability, and validity. Am J Psychiatry (2008) 165(2):203-13. doi:10.1176/appi.ajp.2007. 07010042

51. August SM, Kiwanuka JN, McMahon RP, Gold JM. The MATRICS consensus cognitive battery (MCCB): clinical and cognitive correlates. Schizophr Res (2012) 134:76-82. doi:10.1016/j.schres.2011.10.015

52. Lehrl S. Mehrfachwahl-Wortschatz-Intelligenz-Test. Balingen: Spitta Verlag (1999).

53. Dunn LM, Dunn L. Peabody Picture Vocabulary Test: Deutschsprachige Fassung für Jugendliche und Erwachsene. In: von Bulheller S, und Häcker H, editors. Frankfurt am Main: Swets Test Services (2003).

54. Horn W. L-P-S Leistungsprüfsystem. 2. Auflage. Göttingen: Hogrefe (1983).

55. Beck LH, Bransome ED Jr, Mirsky AF, Rosvold HE, Sarason I. A continuous performance-test of brain-damage. J Consult Psychol (1956) 20(5):343-50. doi: $10.1037 / \mathrm{h} 0043220$

56. Moosbrugger H, Oelschlägel J. FAIR - Frankfurter Aufmerksamkeits-Inventar. Bern: Huber (1996).

57. Spreen O, Strauss E. A Compendium of Neuropsychological Tests: Administration, Norms and Commentary. New York: Oxford University Press (1991).

58. Zimmermann P, Fimm BTAP. Testbatterie zur Aufmerksamkeitsprüfung (Version 2.1). Herzogenrath: Psytest (2007).

59. Reitan RM, Wolfson D. The Halstead-Reitan Neuropsychological Test Battery: Therapy and Clinical Interpretation. Tucson, AZ: Neuropsychological Press (1985).

60. Helmstaedter C, Lendt M, Lux S. Verbaler Lern-and Merkfähigkeitstest (VLMT). Göttingen: Hogrefe (2001).

61. Helmstaedter C, Durmen HF. VLMT: verbaler Lern- and merkfähigkeitstest. Ein praktikables and differenziertes instrumentarium zur Prüfung der verbalen gedächtnisleistung. Schweiz Arch Neurol Psychiatr (1990) 141:21-30.

62. Aschenbrenner S, et al. Regensburger Word Fluency Test (Regensburger Wortflüssigkeitstest). Göttingen: Hogrefe (2000).

63. Aschenbrenner A, Tucha O, Lange K. Regensburger Wortflüssigkeits-Test. Handanweisung. Göttingen: Hogrefe (2000).

64. Aster M, Neubauer A, Horn R. Wechsler Intelligenztest Für Erwachsene (WIE): Deutschsprachige Bearbeitung and Adaptation des WAIS-III von David Wechsler. Frankfurt: Harcourt Test Services (2006).

65. Drühe-Wienholt CH, Wienholt W. Computergestütztes Kartensortierverfahren: Modifizierte Version des Wisconsin Kartensortiertests. Frankfurt am Main: Hartcourt Testservices (2004).

66. Gediga G, Schöttke H. Die Türme von Hanoi oder computersimulierte Problemlöseszenarien. In: Funke J, editor. Denken und Problemlösen. Göttingen: Hogrefe (2006).

67. Simon JJ, Biller A, Walther S, Roesch-Ely D, Stippich C, Weisbrod M, et al. Neural correlates of reward processing in schizophrenia-relationship to apathy and depression. Schizophr Res (2010) 118:154-61. doi:10.1016/j.schres.2009. 11.007

68. Buchner H, Adams L, Müller A, Ludwig I, Knepper A, Thron A, et al. Somatotopy of human hand somatosensory cortex revealed by dipole source analysis of early somatosensory evoked potentials and 3D-NMR tomography. Electroencephalogr Clin Neurophysiol (1995) 96(2):121-34. doi:10.1016/0168-5597(94) 00228-7

69. Norra C, Waberski TD, Kawohl W, Kunert HJ, Hock D, Gobbelé R, et al. Highfrequency somatosensory thalamocortical oscillations and psychopathology in schizophrenia. Neuropsychobiology (2004) 49(2):71-80. doi:10.1159/ 000076413

70. Juckel G, Hegerl U, Giegling I, Mavrogiorgou P, Wutzler A, Schuhmacher C, et al. Association of 5-HT1B receptor polymorphisms with the loudness dependence of auditory evoked potentials in a community-based sample of healthy volunteers. Am J Med Genet (2008) 147B(4):454-8. doi:10.1002/ajmg.b.30628

71. Kawohl W, Giegling I, Mavrogiorgou P, Pogarell O, Mulert C, Möller HJ, et al. Association of functional polymorphisms in NOS1 and NOS3 with loudness dependence of auditory evoked potentials. Int J Neuropsychopharmacol (2008) 11(4):477-83. doi:10.1017/S1461145708008420

72. Gudlowski Y, Özgürdal S, Witthaus H, Gallinat J, Hauser M, Winter C, et al. Serotonergic dysfunction in the prodromal, first-episode and chronic course of schizophrenia as assessed by the loudness dependence of auditory evoked activity. Schizophr Res (2009) 109(13):141-7. doi:10.1016/j.schres.2009.02.008

73. Juckel G, Gallinat J, Riedel M, Sokullu S, Schulz C, Möller HJ, et al. Serotonergic dysfunction in schizophrenia assessed by the loudness dependence measure of primary auditory cortex evoked activity. Schizophr Res (2003) 64(2-3):115-24. doi:10.1016/S0920-9964(03)00016-1

74. Juckel G, Kawohl W, Giegling I, Mavrogiorgou P, Winter C, Pogarell O, et al. Association of catechol-O-methyltransferase variants with loudness dependence of auditory evoked potentials. Hum Psychopharmacol (2008) 23(2):115-20. doi:10.1002/hup.906

75. Wyss C, Hitz K, Hengartner MP, Obermann C, Uhl I, Roser P, et al. The loudness dependence of auditory evoked potentials (LDAEP) as an indicator of serotonergic dysfunction in patients with predominant schizophrenic negative symptoms. PLoS One (2013) 8(7):e68650. doi:10.1371/journal.pone.0068650

76. Näätänen R. The mismatch negativity: a powerful tool for cognitive neuroscience. Ear Hear (1995) 16(1):6-18. doi:10.1097/00003446-199502000-00002

77. Picton TW, Alain C, Otten L, Ritter W, Achim A. Mismatch negativity: different water in the same river. Audiol Neurootol (2000) 5(3-4):111-39. doi:10.1159/000013875

78. Heekeren K, Daumann J, Neukirch A, Stock C, Kawohl W, Norra C, et al. Mismatch negativity generation in the human 5HT2A agonist and NMDA antagonist model of psychosis. Psychopharmacology (2008) 199(1):77-88. doi:10.1007/s00213-008-1129-4

79. Umbricht D, Krljes S. Mismatch negativity in schizophrenia: a meta-analysis. Schizophr Res (2005) 76(1):1-23. doi:10.1016/j.schres.2004.12.002

80. Fallgatter AJ, Strik WK. The NoGo-anteriorization as a neurophysiological standard-index for cognitive response control. Int J Psychophysiol (1999) 32(3):233-8. doi:10.1016/S0167-8760(99)00018-5

81. Fallgatter AJ. Electrophysiology of the prefrontal cortex in healthy controls and schizophrenic patients: a review. J Neural Transm (2001) 108(6):679-94. doi:10.1007/s007020170045

82. Ehlis AC, Herrmann MJ, Plichta MM, Fallgatter AJ. Cortical activation during two verbal fluency tasks in schizophrenic patients and healthy controls as assessed by multi-channel near-infrared spectroscopy. Psychiatry Res (2007) 156(1):1-13. doi:10.1016/j.pscychresns.2006.11.007

83. Herrmann MJ, Ehlis AC, Fallgatter AJ. Frontal activation during a verbalfluency task as measured by near-infrared spectroscopy. Brain Res Bull (2003) 61(1):51-6. doi:10.1016/S0361-9230(03)00066-2

84. Williams JMG, Mathews A, MacLeod C. The emotional stroop task and psychopathology. Psychol Bull (1996) 120(1):3-24. doi:10.1037/0033-2909. 120.1.3

85. Dresler T, Ehlis AC, Plichta MM, Richter MM, Jabs B, Lesch KP, et al. Panic disorder and a possible treatment approach by means of high-frequency rTMS: a case report. World J Biol Psychiatry (2009) 10(4 Pt 3):991-7. doi:10.1080/15622970902898147

86. Haker H, Rössler W. Empathy in schizophrenia: impaired resonance. Eur Arch Psychiatry Clin Neurosci (2009) 259(6):352-61. doi:10.1007/s00406-0090007-3

87. Haker H, Kawohl W, Herwig U, Rössler W. Mirror neuron activity during contagious yawning-an fMRI study. Brain Imaging Behav (2013) 7(1):28-34 doi:10.1007/s11682-012-9189-9 
88. Gur RC, Ragland JD, Moberg PJ, Turner TH, Bilker WB, Kohler C, et al. Computerized neurocognitive scanning: I. methodology and validation in healthy people. Neuropsychopharmacology (2001) 25(5):766-76. doi:10.1016/S0893133X(01)00278-0

89. Gur RC, Ragland JD, Moberg PJ, Bilker WB, Kohler C, Siegel SJ, et al. Computerized neurocognitive scanning: II. the profile of schizophrenia. Neuropsychopharmacology (2001) 25(5):777-88. doi:10.1016/S0893-133X(01) 00279-2

90. Gur RC, Sara R, Hagendoorn M, Marom O, Hughett P, Macy L, et al. A method for obtaining 3-dimensional facial expressions and its standardization for use in neurocognitive studies. J Neurosci Methods (2002) 115(2):137-43. doi:10.1016/S0165-0270(02)00006-7

91. Erwin RJ, Gur RC, Gur RE, Skolnick B, Mawhinney-Hee M, Smailis J. Facial emotion discrimination: I. task construction and behavioral findings in normal subjects. Psychiatry Res (1992) 42(3):231-40. doi:10.1016/0165-1781(92) 90115-J

92. Sachs G, Steger-Wuchse D, Kryspin-Exner I, Gur RC, Katschnig H. Facial recognition deficits and cognition in schizophrenia. Schizophr Res (2004) 68(1):27-35. doi:10.1016/S0920-9964(03)00131-2

93. Baron-Cohen S, Jolliffe T, Mortimore C, Robertson M. Another advanced test of theory of mind: evidence from very high functioning adults with autism or asperger syndrome. J Child Psychol Psychiatry (1997) 38(7):813-22. doi:10.1111/j.1469-7610.1997.tb01599.x

94. Kelley HH, Levine D. Attribution theory in social psychology Nebraska symposium on motivation. Lincoln: University of Nebraska Press (1967).

95. Rössler W, Lackus B. Cognitive disorders in schizophrenics viewed from the attribution theory. Eur Arch Psychiatry Neurol Sci (1986) 235(6):382-7. doi:10.1007/BF00381009

96. David N, Newen A, Vogeley K. The "sense of agency" and its underlying cognitive and neural mechanisms. Conscious Cogn (2008) 17(2):523-34. doi:10.1016/j.concog.2008.03.004

97. Schimansky J, David N, Rössler W, Haker H. Sense of agency and mentalizing: dissociation of subdomains of social cognition in patients with schizophrenia. Psychiatry Res (2010) 178(1):39-45. doi:10.1016/j.psychres.2010.04.002

98. Davis MH. A multidimensional approach to individual differences in empathy. Catalog Select Doc Psychol (1980) 10:85-100.

99. Haker H, Schimansky J, Jann S, Rössler W. Self-reported empathic abilities in schizophrenia: a longitudinal perspective. Psychiatry Res (2010) 200(23):1028-31. doi:10.1016/j.psychres.2012.04.004

100. Link BG. Understanding labeling effects in the area of mental disorders: an assessment of the effects of expectations of rejection. Am Sociol Rev (1987) 52:96-112. doi:10.2307/2095395

101. Rüsch N, Lieb K, Bohus M, Corrigan PW. Self-stigma, empowerment, and perceived legitimacy of discrimination among women with mental illness. Psychiatr Serv (2006) 57:399-402. doi:10.1176/appi.ps.57.3.399

102. Schmader T, Major B, Eccleston CP, McCoy SK. Devaluing domains in response to threatening intergroup comparisons: perceived legitimacy and the status value asymmetry. J Pers Soc Psychol (2001) 80:782-96. doi:10.1037/0022-3514. 80.5.782

103. Rosenberg M. Society and the Adolescent Self-Image. Princeton: Princeton University Press (1965).

104. Bogardus ES. Social distance and its origins. J Appl Sociol (1925) 9:216-26.

105. Rüsch N, Corrigan PW, Wassel A, Michaels P, Olschewski M, Wilkniss $\mathrm{S}$, et al. A stress-coping model of mental illness stigma: I. predictors of cognitive stress appraisal. Schizophr Res (2009) 110:59-64. doi:10.1016/j.schres. 2009.01 .006

106. Rüsch N, Corrigan PW, Powell K, Rajah A, Olschewski M, Wilkniss S, et al. A stress coping model of mental illness stigma: II. emotional stress responses, coping behaviour and outcome. Schizophr Res (2009) 110:65-71. doi:10.1016/j.schres.2009.01.005

107. Kaiser CR, Major B, McCoy SK. Expectations about the future and the emotional consequences of perceiving prejudice. Pers Socal Psychol Bull (2004) 30:173-84. doi:10.1177/0146167203259927

108. Rüsch N, Corrigan PW, Wassel A, Michaels P, Olschewski M, Wilkniss S, et al. Ingroup perception and responses to stigma among persons with mental illness. Acta Psychiatr Scand (2009) 120:320-8. doi:10.1111/j.1600-0447.2009. 01403.x
109. Jetten J, Branscombe NR, Schmitt MT, Spears R. Rebels with a cause: group identification as a response to perceived discrimination from the mainstream. Pers Soc Psychol Bull (2001) 27:1204-13. doi:10.1177/0146167201279012

110. Addington J, Cadenhead KS, Cannon TD, Cornblatt B, McGlashan TH, Perkins DO, et al. North American prodrome longitudinal study: a collaborative multisite approach to prodromal schizophrenia research. Schizophr Bull (2007) 33(3):665-72. doi:10.1093/schbul/sbl075

111. Martin DJ, Smith DJ. Is there a clinical prodrome of bipolar disorder? A review of the evidence. Expert Rev Neurother (2013) 13(1):89-98. doi:10.1586/ ern.12.149

112. Bechdolf A, Ratheesh A, Wood SJ, Tecic T, Conus P, Nelson B, et al. Rationale and first results of developing at-risk (prodromal) criteria for bipolar disorder. Curr Pharm Des (2012) 18(4):358-75. doi:10.2174/138161212799316226

113. Angst J. The bipolar spectrum. Br J Psychiatry (2007) 190:189-91. doi:10.1192/ bjp.bp. 106.030957

114. Vandeleur CL, Merikangas KR, Strippoli MP, Castelao E, Preisig M. Specificity of psychosis, mania and major depression in a contemporary family study. $\mathrm{Mol}$ Psychiatry (2014) 19(2):209-13. doi:10.1038/mp.2013.132

115. Merikangas KR, Cui L, Heaton L, Nakamura E, Roca C, Ding J, et al. Independence of familial transmission of mania and depression: results of the NIMH family study of affective spectrum disorders. Mol Psychiatry (2014) 19(2):214-9. doi:10.1038/mp.2013.116

116. Metzler S, Dvorsky D, Wyss C, Müller M, Traber-Walker N, Walitza S, et al. Neurocognitive profiles in help-seeking individuals: comparison of risk for psychosis and bipolar disorder criteria. Psychol Med (2014) 17:1-13. doi:10.1017/S0033291714001007

117. Addington J, Heinssen R. Prediction and prevention of psychosis in youth at clinical high risk. Annu Rev Clin Psychol (2012) 8:269-89. doi:10.1146/ annurev-clinpsy-032511-143146

118. Addington J, Cornblatt BA, Cadenhead KS, Cannon TD, McGlashan TH, Perkins DO, et al. At clinical high risk for psychosis: outcome for nonconverters. Am J Psychiatry (2011) 168(8):800-5. doi:10.1176/appi.ajp.2011.10081191

119. McGorry PD, Killackey E, Yung A. Early intervention in psychosis: concepts, evidence and future directions. World Psychiatry (2008) 7(3):148-56. doi:10.1002/j.2051-5545.2008.tb00182.x

120. Rüsch N, Heekeren K, Theodoridou A, Dvorsky D, Müller M, Paust T, et al. Attitudes towards help-seeking and stigma among young people at risk for psychosis. Psychiatry Res (2013) 210(3):1313-15. doi:10.1016/j.psychres.2013. 08.028

121. Rüsch N, Corrigan PW, Heekeren K, Theodoridou A, Dvorsky D, Metzler S, et al. Well-being among persons at risk of psychosis: the role of self-labeling, shame, and stigma stress. Psychiatr Serv (2014) 65(4):483-9. doi:10.1176/appi.ps.201300169

122. Rüsch N, Müller M, Heekeren K, Theodoridou A, Metzler S, Dvorsky D, et al. Longitudinal course of self-labeling, stigma stress and well-being among young people at risk of psychosis. Schizophr Res (2014) 158(1-3):82-4. doi:10.1016/j.schres.2014.07.016

Conflict of Interest Statement: The authors declare that the research was conducted in the absence of any commercial or financial relationships that could be construed as a potential conflict of interest.

Received: 05 June 2014; accepted: 14 September 2014; published online: 01 October 2014.

Citation: Theodoridou A, Heekeren K, Dvorsky D, Metzler S, Franscini M, Haker H, Kawohl W, Rüsch N, Walitza S and Rössler W (2014) Early recognition of high risk of bipolar disorder and psychosis: an overview of the ZInEP "early recognition" study. Front. Public Health 2:166. doi: 10.3389/fpubh.2014.00166

This article was submitted to Public Mental Health, a section of the journal Frontiers in Public Health.

Copyright (C) 2014 Theodoridou, Heekeren, Dvorsky, Metzler, Franscini, Haker, Kawohl, Rüsch, Walitza and Rössler. This is an open-access article distributed under the terms of the Creative Commons Attribution License (CC BY). The use, distribution or reproduction in other forums is permitted, provided the original author (s) or licensor are credited and that the original publication in this journal is cited, in accordance with accepted academic practice. No use, distribution or reproduction is permitted which does not comply with these terms. 